\title{
Let's Start a Riot: The Effects of Protest Characteristics on Democratic Progress
}

Author: Joshua T. Counselman

Faculty Mentors: John Ishiyama, Ph.D. and Angela Nichols, Ph.D. Candidate, Department of Political Science, College of Arts and Sciences, University of North Texas

College and Affiliation: Department of History, Philosophy, Political Science, and Religion Marietta College 


\section{Bio:}

Joshua T. Counselman is a senior majoring in political science at Marietta College. He discovered his interests in protests while studying in St. Petersburg, Russia, during the Spring 2012 semester. After having witnessed some anti-Putin rallies, he became interested in how protests affect democratic progress. Upon graduation from Marietta College, he plans to pursue a Ph.D. in political science and to continue researching how protest characteristics affect democratic progress in states. 


\begin{abstract}
:
Recent literature on protests begins to identify the differences between violent and nonviolent movements. These studies, however, fail to unpack other key characteristics of protests. In an attempt to better understand how different types of protests impact democratic progress, I examine four key protest characteristics_-violence, size, location, and duration. I argue that violent protests and larger protests are less likely to cause democratic progress while more widespread protests and longer protests are more likely to lead to democratic progress in weak states. Using a logistic analysis, I examine the relationship between the four characteristics and democratic progress in countries that experienced protests from 1960 to 2006. Nonviolent movements are found to have a positive and significant effect on democratic progress, while protest size seems to have a negative and significant relationship on democratic progress. These findings imply that while larger protests do not lead to democracy, primarily nonviolent movements do cause democratic progress.
\end{abstract}




\section{Introduction}

With the Arab Spring movement in 2011 and protests in Egypt in 2013, protests are on center stage internationally with their ability to produce political change within states. The effects that different characteristics of protests have on democracy are vital to protesters who want their country to make democratic progress. If protesters are aware of the characteristics that help democracy, they are able to shape the protests in regards to these characteristics.

How do the characteristics of protests affect progress toward democracy or a retreat to authoritarianism? Some countries that were democratized by the recent Arab Spring movements in 2011 are facing protests from their citizens. Not all protests, however, within countries share identical characteristics. This is a timely question in recently democratizing or liberalizing countries, in regards to protests. In addition, the literature breaks protests down only into nonviolent and violent protests, leaving other aspects of protests understudied. I argue that certain characteristics - violence, size, location, and duration - of the protests that arise within weak democracies determine whether these new governments continue to make democratic progress.

The cost to protest decreases as governments begin to liberalize. Citizens are still able to protest without states liberalizing, but the costs will be higher. When citizens take to the streets, larger protests and violence are less likely to produce democratic progress while diversity in location and duration are more likely to cause democratic progress. The results of this study indicate larger and violent protests are both less likely to move states closer to democracy.

In the next section, I discuss the existing literature. In the third section, I develop a theory along with four hypotheses that I use to test the importance of size, violence, duration, and location of different protests. In the fourth section of the paper, I explain my dependent and 
independent variables. In the final section, I discuss the findings of this study. Finally, I indicate some areas for future research based on my findings.

\section{Literature Review}

Huntington (1991) describes different authoritarian regimes as well as different ways that countries transition towards democracy. Mainwaring (1989) discusses how protests and repression are affected by authoritarian states that began to liberalize. This is important because

it lowers the cost for opposition groups and opens the door for protest movements. Lichbach and Gurr (1981) and Lichbach (1987) introduce the effects that state repression has on protest movements, and how the government's decision can end the protests or escalate them. Chenoweth and Stephan (2008) and Cunningham (2013) break down protests into violent and nonviolent movements.

\section{Transitions to Democracy}

Huntington states that the nondemocratic regimes that underwent democratic transitions during the third wave of democracy can be divided into three categories: one-party systems, military regimes, and personal dictatorships (1991). In one-party systems, there is only one dominating party and access to positions within the government is only through that party. Military governments come into existence through a military coup. In personal dictatorships, one individual has authority, and power comes only from that individual ruler.

Huntington (1991) focuses on three types of transitions: transformation, replacement, and transplacement. Transformation occurs when elites who are already in power begin the movement toward democracy; replacement is when opposition groups lead the country toward democracy; and transplacement is when the government and opposition groups work together to transition toward democracy. 
For Huntington, the current authoritarian elite have to begin the move toward democracy (1991). Authoritarian governments that were liberalizing could move toward democracy or away from democracy. When liberalization begins, it raises the hopes of citizens for further change, and when those changes do not come, it creates instability that moves the state away from democracy. In South Africa, the presence of protests ended the government's attempts at liberalization. Although Huntington discusses the presence of protests in countries, he does not go into detail about the characteristics of the movements. That is where this study hopes to expand on the literature by breaking down the characteristics of protests into violence, size, location, and duration.

Mainwaring (1989) discusses the difference between liberalization and democratization. Liberalization is described as the easing of repression used by the state and the expansion of civil liberties, while democratization is described as a movement toward democracy. Democratic transitions begin with divisions within the government. Agreeing with Huntington (1991), Mainwaring recognizes that liberalization does not always lead to democracy. However, liberalization creates greater opportunities by decreasing costs for citizens to express dissent and protest the authoritarian government.

Geddes (1999) describes the same three types of authoritarian states as Huntington, but concludes that negotiations are more likely to occur under military rule than a personalist dictatorship. The latter usually have transitions that are extremely quick and frenzied compared to the negotiations that occur under military regimes. For negotiations to occur, however, there have to be stable political parties that are able to negotiate and keep their end of the bargain. An authoritarian government that is unified can use force against its citizens, but it cannot survive by 
the use of force alone. It is in the government's best interest to seek a peaceful transition to democracy through liberalization rather than resort to the use of violence to maintain power.

Beissinger (2007) explains countries that democratize are not individual cases but are interconnected. A state's chance to democratize improves by six to ten percent with each democratic country that is within its geographic region. Beissinger claims that the democratization of post-communist states in 2000 offers examples of a modular democratic revolution. Each state that successfully transitioned toward democracy after communism had other states try to follow in its footsteps. Each successful example raised the hopes of other states that they would be successful in their own movement.

Beissinger (2007) discovered that larger groups mobilized more quickly than smaller groups. In the early days of an opposition movement, the size of the protests is an important factor because it sets an example for the population. Protests are more likely to arise in states that have already begun to liberalize, which is a similar finding to that of Huntington (1991) and Mainwaring (1989). Large protests that occur throughout a country demoralize the authoritarian government in power. Beissinger states that large protests should lead to democracy since the population is used to mobilizing large numbers of citizens. Serbia, Georgia, and Ukraine succeeded in their revolutions through large protests, but Kyrgyzstan's movement succeeded only because of violence.

\section{State Repression}

Lichbach and Gurr $(1981,5)$ define protests as an "open political conflict which centers on the policies followed by regimes" that includes political demonstrations, riots, and general strikes. The decision for states to use repression could have unintended consequences. They argue that as protests become larger, the government will be more likely to use force to disperse 
the movement; governments, however, may not want to alienate large portions of the citizenry by using violent tactics. Governments originally use violence to prevent future protests, but violence can cause future protests by drawing outsiders into the movement.

One criticism of the work of Lichbach and Gurr (1981) is that they combine all of the factions within a protest into a single opposition group. Instead of viewing the ideas and behavior of specific opposition groups, the authors combine them all together under one umbrella of opposition. This strategy is good for studies that are comparing the opposition as a whole, but by combining all the characteristics of protests into a single group, it is impossible to identify which characteristics lead to democratic progress.

According to Lichbach (1987), government repression can have the opposite effect of its intended purpose. When a government uses repressive tactics, it weakens the government's legitimacy and primes the country's revolutionary potential. The repression from the state becomes a target for those who are new to the movement. As states become more repressive, the potential increases for opposition groups to mobilize. Repression of nonviolent protests may cause the protests to disperse, but opposition groups are then more likely to use violent tactics. Lichbach discovered that when governments are consistent with their tactics, dissent is decreased. The opposition's decision to turn a movement violent is based on the actions of the government.

A government has both external and internal restraints when deciding to repress the opposition (Gartner and Regan 1996). International states may accept repression if it is equal to the demands of the opposition, but when the international community sees a government use excessive tactics, less repression is accepted. Domestically, the government has to respond to the opposition appropriately or it will lose the confidence of the state's elites. Both domestic and 
international costs depend on the demands of the opposition group, and as the demands change, the costs and benefits of repression change both internationally and domestically.

\section{Nonviolent and Violent Protests}

The existing literature has begun to break protests down into nonviolent and violent protests. The main findings of Kalandadze and Orenstein (2009) show that electoral revolutions that ended successfully had little impact on democratic progress. Although electoral revolutions fight for the right of citizens to vote, such protests are mostly symptoms of the problem instead of a long-term solution. Even in successful electoral protests, other issues remained that the new government had to confront once in power. These other problems remained because electoral revolutions typically focus only on the most recent election results. Electoral protests often arise out of a fraudulent election, and the opposition resorts to mass demonstrations to protect democratic rights. In failed electoral revolutions, the government met the protests with violence.

Democratic progress is also affected by which region of a country undergoes electoral revolutions. Kalandadze and Orenstein (2009) provide the example of Madagascar, a country that did not have an opportunity to join international organizations such as the EU or NATO that help with democratic progress. Serbia, however, had a chance to join the EU so long as it continued progress toward democracy.

Chenoweth and Stephan's (2008) main findings were that nonviolent protests achieved success fifty-three percent of the time, and violent protests achieved success only twenty-six percent of the time. Nonviolent campaigns create legitimacy which generates broad participation within the movement, and it is harder for governments to justify the use of violence. The use of violence does not force the government to make concessions, but rather allows it to repress the protests. 
Members of the government are more likely to be sympathetic toward nonviolent protests than violent protests (Chenoweth and Stephan 2008). In addition, the government is more likely to negotiate with the opposition if they use nonviolent protests instead of violence. Nonviolent protests that face violent repression are also more likely to receive support from outside states.

Cunningham's (2013) main focus is to examine the costs of the different strategies that groups who seek self-determination can use to achieve their goal. The strategies that these groups can use are either to remain silent, use established political channels, or use violence or nonviolent protests. Using established political channels is the least costly method to follow, while nonviolent and violent protests are more costly and have better chances at success. When groups are larger, they are more likely to resort to violence while smaller groups are more likely to be nonviolent.

Nonviolent tactics include strikes, protests, sit-ins, and direct action that exclude voting while violent tactics include civil war and acts of terrorism (Cunningham 2013). Cunningham argues that for nonviolent protests to be successful there has to be a large number of participants to pressure the state. This, however, goes against what Cunningham stated earlier in the article about larger groups being more likely to engage in violent tactics.

Cunningham's contradiction in this piece of literature casts doubt on whether larger groups are actually more likely to become violent, a key point of the author. At the beginning of the article, Cunningham describes smaller protests as more likely to be less violent during protests, and existing literature verifies that nonviolent protests are more likely to succeed.

Despite the existing literature, further research is required to understand how protest characteristics affect weak regimes. The majority of the literature cited examines only the effects that protests have on democratic progress in general. Violence, size, location, and duration are 
lumped together and authors study only the effect of protests as a whole. If authors do begin to break protests down, they stop at nonviolent and violent protests without examining the effect of other characteristics. This study attempts to fill this gap in the literature on protests and democratization by unpacking characteristics into violence, size, location, and duration.

\section{Theory}

Taking this step will allow us to solve the puzzle of how protests affect democracy. Before citizens begin protesting, it is important for a government to go through a period of liberalization (Lichbach and Gurr 1981). As the state begins to ease its use of repression and expands civil liberties, the cost for citizens to protest decreases significantly (Mainwaring 1989). Citizens then come to expect more changes than the government had originally planned under its policy of liberalization, which causes protests (Huntington 1991). At this point, the government is more likely to use force to end protests if it has not begun to liberalize. Thus, the first assumption of this project is that liberalization decreases the cost for citizens to begin protesting. This assumption does not assume that citizens are only able to protest the government when it begins to liberalize, but it decreases the costs to protest.

After protests have begun, they are able to move the country closer to democracy or authoritarianism. Another key assumption is that each protest has different characteristics. No protest will be exactly the same across all of its characteristics. This study focuses on violence, size, location, and duration. Each characteristic has the opportunity to affect democratic progress.

Another assumption is that protesters account for the response of the government when deciding to protest. Although a repressive government's policies cause the citizens to want to protest, the costs of protesting against a repressive government may be too high. This means that 
the more repressive a state, the higher the cost of protesting. Protesters have to decide between the high costs associated with protesting or their unhappiness toward the government. If the government is consistent in its policies, it has a better chance to deter future protests. Conrad and DeMeritt (2011) find that governments use a variety of repressive tactics. The Shah of Iran, for instance, switched between concessions and repression (Rasler 1996). These varied policies caused the protests to become larger than if he used a constant tactic.

Some characteristics of protests elicit a more repressive response from the government rather than concessions. Another assumption is that repression causes less democratic progress while concessions are more likely to produce democratic progress. Governments are more likely to utilize repressive tactics when they feel threatened by protests. Certain characteristics concern the government about its ability to stay in power, which invites repression.

If a state tries to repress protests, it attempts to raise the costs of organizing as a way to prevent future movements. By raising the costs, the government tries to secure its position in power by making it too costly to continue protesting. When protesters are no longer able to take to the streets, the government is able to maintain its power. In Iran, the Shah used repression to prevent future protests. As the cost to protest increases, citizens have to decide if the costs outweigh the benefits of continued protests.

Once the cost becomes high, citizens have to decide if their unhappiness with the government is enough to continue their efforts. Citizens face especially high costs if they decide to protest against a government that has not begun to liberalize, so they have to weigh their options of whether it is worth protesting against the government. If the citizens believe that the costs outweigh the benefits of protesting, the government's use of repression has achieved its goal and prevented future protests. 
Characteristics that do not cause repression invite government concessions. If the government views the characteristics displayed by protests to be nonthreatening, it will be more likely to make concessions to the protesters. In the Dominican Republic, for example, protests were not excessively violent, which allowed the government to make concessions. If the government does not believe that it can immediately dismantle the current protests, it will be more likely to make concessions instead of using repression.

Government concessions to protesters move the country toward democracy instead of toward repressive authoritarian tactics. When the government makes concessions, the state will move closer to democracy. The demands of the protesters may lead the country away from a repressive state, as by not repressing its citizens, the state makes a positive move in regards to democratic progress. The spirit of cooperation and concessions aids the state as it progresses to democracy.

Hypothesis \#1: As protests become more violent, the government is less likely to become democratic.

Protests that are exceedingly violent cause governments to give up on liberalization or democratization. The more violence that occurs during protests will require the government to become more repressive to suppress future movements. With South Africa, the apartheid government began to liberalize, but violent protests ended those government policies (Huntington 1991). As the two examples indicate, excessive violence appears not to produce a movement in the direction of democracy. In the Dominican Republic, there was some violence during protests but not an excessive amount (Espinal 1995). However, the Dominican Republic remained democratic. Excessive use of violence during protests decreases a state's likelihood of democratic progress. 
Hypothesis \#2: As the size of the protests increases, the government is less likely to become democratic.

Size is another characteristic that varies between different protests. In the case of Iran, protests against the Shah grew to large numbers that included many different opposition groups. The size of the protests in Iran did not lead to democratic progress, however, but rather an Islamic state (Rasler 1996). Larger protests create the opportunity for different factions of the population to become involved in the protests. When more groups become involved, the original message of the movement gets lost. Also, as the protests increase, the government is more likely to try to disband the protesters through the use of force. The threat from larger protests entices the government into the use of force to try and increase the costs of continued protests. Hypothesis \#3: As protests spread throughout the state, the government is more likely to become more democratic.

The location of protests also affects the transition to democracy or a retreat back to an authoritarian government. If the protests extend outside of the capital and into other major cities, the government is forced to respond to the protesters through concessions. If protests remain within the capital, however, the government is more likely to respond with repression instead of concessions. As protests spread to more cities, this expansion makes it more difficult for the government to completely repress the movement. The expansion of protests requires the government to exhaust more of its resources to repress protests. Concessions made by the government as the protests expand create democratic progress.

Hypothesis \#4: When protests are longer, the government is more likely to become democratic. 
Longer protests also affect a county's democratic progress. Governments are more likely to provide concessions if protests continue to drag on for an extended period of time. Protests of longer duration indicate that the government is unable to stop the protests. The longer that protests continue, the higher the costs for the government, because it shows that the regime is unable to end the movements. Protests that have a shorter duration are more likely to be met with repression because the government wants to end the protests. Longer protests cause the government to offer concessions to appease the protesters, which means progress toward democracy.

\section{Research Design}

Four different characteristics of protests are examined in this study: violence, size, location, and duration. The main focus of this study is the effect that these four different characteristics of protests have on democratic progress within states. The lack of GDP per capita data that extends back to 1945 limits this study to the time frame of 1960 to 2006 . The unit of analysis for this study is country year. This section will follow a similar format to that used by Joshi (2010) when he unpacked civil wars.

\section{Democratic Progress}

The dependent variable for this study is democratic progress which is measured by change in the polity2 score after five years. The change in states' polity2 ratings will be measured after five years. Although the data in Polity IV ranges from 1800 to 2012, this project is going to only use the data from 1960 to 2006 . Polity IV has a scale that ranges from -10 to +10 . This scale is then broken down into three different groups: autocracy (-10 to 0$)$, partial democracy (1-6), and full democracy (7-10) (Marshall and Gurr 2013). 
Joshi (2010) required there to be a three point move toward democracy for a state to be considered transitioning to democracy, but this study will only require a two point move toward or away from democracy. Although a two point increase or decrease in a state's polity rating will not always move the state to another group, the movement of the ranking still indicates whether a state experiences democratic progress.

The existing literature that focuses on democratization relies on Polity IV. As mentioned, Joshi used Polity IV to measure democratization, and currently, Polity IV is being used as a measure of democratization in research. Celestino and Gleditsch (2013), Cunningham (2013), and Stephan and Chenoweth (2008) have used Polity IV as their measure of democratization. Polity's continued use by scholars demonstrates that it is an appropriate measure to be used for this study.

\section{Protests}

The main independent variable for this study is protests. However, protests are unpacked into four different characteristics: violence, size, location, and duration. This variable is operationalized through the recently released Nonviolent and Violent Campaigns and Outcomes (NAVCO) 2.0 dataset (Chenoweth and Lewis 2013). The NAVCO 2.0 dataset tracks violent and nonviolent campaigns from 1945 to 2006 . Chenoweth and Lewis (2013) require campaigns to have observable tactics, to be continuous, and have a clear objective. ${ }^{1}$ To be included in the dataset, campaigns are required to have at least 1,000 participants. NAVCO 2.0 includes 100 cases of nonviolent protests and 150 cases of violent movements.

Although NAVCO 2.0 is one of the newest datasets in the field, it is an appropriate measure of protests within states. The Correlates of War dataset includes both domestic and international wars (Chenoweth and Lewis 2013). Also, other databases tend to focus solely on

\footnotetext{
${ }^{1} \mathrm{http}: / /$ www.du.edu/korbel/sie/research/chenow_navco_data.html
} 
violence while leaving out nonviolent conflicts. For example, the Global Nonviolent Action Database is the only dataset to cover global nonviolent movements, but it does not include data on violent movements. While Minorities At Risk-Organization Behavior includes both violent and nonviolent movements, it focuses solely on the Middle East. Based on the limitations of the existing databases, NAVCO 2.0 is an appropriate measure for this study because it includes both nonviolent and violent campaigns on a global scale.

The duration of the protests is defined as the years where the movements had over 1,000 participants. Duration is measured using the cyear measure from NAVCO 2.0 that designates whether a campaign begins, is ongoing, or ended (Chenoweth and Lewis 2013, 6). For this study, the duration of protests ranges from categories of 0 to 4 .

NAVCO 2.0 has both an ordinal measure of the movement's size and an estimated measure of the number of participants. This study focuses on the ordinal measure, camp_size, of the number of participants within a movement. There are five intervals that range from one to over one million participants in the movement (Chenoweth and Lewis 2013). This study, however, does not use the ranges provided in NAVCO 2.0. If states have multiple protests in a year, this study will combine the different protests into one movement. This allows the study to better measure the total size of protests within a year.

For location, this study uses NAVCO 2.0's data for urban-rural diversity. NAVCO's operationalization of this variable, cdivers_urbrural, is whether movements "embrace urbanrural diversity" (Chenoweth and Lewis 2013, 7). This characteristic examines whether there are both urban and rural protests within the movement.

The last characteristic this study examines is whether the movement was primarily nonviolent or violent. This variable, prim_method, is operationalized as "the primary type of 
resistance method used in a campaign year" (Chenoweth and Lewis 2013, 6). This study uses the designate from NAVCO 2.0 to test whether primarily violent or nonviolent campaigns lead to democratic progress.

\section{Protest Control Characteristics}

This study controls for certain other characteristics within protests. The first control characteristic is the movement's goal. NAVCO allows for five goals that include regime change, institutional reform, policy change, territorial secession, greater autonomy, and anti-occupation (Chenoweth and Lewis 2013). Regime change is coded as a 0 while anti-occupation is coded as a 5. For this study, campaigns that were anti-occupation in nature are not included since the movements are not focused at the state's government but a foreign occupier. The goals of the group will have an impact on the direction of the protests and whether they lead to democracy or authoritarianism.

Another control is whether the state represses the opposition movement. NAVCO has four different levels of repression: none, mild repression, moderate repression, and extreme repression. A state's decision to repress can also have an effect on democratic progress. The effect of state repression, camp_backlash, is also a control for this study. State repression can suppress the movement, decrease domestic mobilization, increase domestic mobilization, or there is no repression from the state. The final characteristic control for this study is diaspora support within the country. This control characteristic indicates whether protest movements gain support from groups that are not involved with the movement.

\section{Controls}

The first control variable for this study is economic development. This control is measured by the average income levels within a state, GDP per capita. As a control, GDP per 
capita is used by Celestino and Gleditsch (2013) in their study of the effect that nonviolent and violent protests have on democratic transitions. This study uses GDP per capita data from the World Bank (World Development Indicators 2013). The level of a state's income is a relevant control variable for a transition to democracy because wealthier states will be more likely to have nonviolent protests (Celestino and Gleditsch 2013).

The next control variable is ethnic populations within a state. This control is measured by ethnic fractionalization within the borders of a state (Fearon and Laitin 2003). Jalali and Lipset $(1992,586)$ state that only 12 out of 132 nations are described as homogenous with a single ethnicity. The lack of homogenous states makes this control variable relevant to this research question. States that are divided along ethnic lines are less likely to succeed in causing democratic progress (Chenoweth and Stephan 2008).

The final control variable for this study is the region in which the state is located (Fearon and Laitin 2003). Some locations are more likely to produce democratic transitions than other regions. After the fall of Yugoslavia, Serbia had the opportunity to work toward democracy with the goal of joining the EU (Kalandadze and Orenstein 2009). On the other hand, Madagascar did not have the opportunity to join an international organization that bases membership on whether a state is a democracy. The region in which the state is located is another relevant control variable for this study.

\section{Method}

This study is going to be tested by using a logistical regression analysis. This type of regression analysis is used when the outcome of the dependent variable is a dichotomous outcome. The two outcomes possible in this study are a change in polity 2 score of at least two points after five years or no change over two points after five years. Since the outcome of the 
dependent variable for this project is dichotomous, a logistical regression analysis is the appropriate test to use of this study.

For testing hypotheses, the standard to reject the null is a statistical significance in the ninetieth percentile. Statistical significance at this level will show correlation and allow for the rejection of the null hypothesis. This study will also include tests for multicollinearity between the characteristics of protests. By testing for multicollinearity, this study is able to fully indicate correlation between certain protest characteristics and democratic progress.

\section{Analysis}

The results of this study begin to offer insights into the effect of protest characteristics on democratic progress. Two of the four characteristics, size and violence, prove to be statistically significant. Both variables follow the theorized effect on democratic progress.

Table 1 presents the results of the logistic regression with the unit of analysis being country year. A negative indicates the variable does not cause democratic progress. Conversely, a positive indicates that the variable does cause democratic progress within a state. Two independent variables of interest indicate a negative relationship. Nonviolence is the only significant variable of interest that has a positive relationship with democratic progress after five years.

When protests spread beyond the capital, it is expanding to more citizens. The diversity in locations of protests is not statistically significant for this study. The spread of location for protests outside of the capital does not have an effect on whether states experience democratic progress. Even though more citizens are reached by the protests expanding beyond the capital, it does not have a statistically significant effect on a state's democratic progress after five years. 
As campaigns begin to grow larger, the probability of democratic progress decreases. According to Table 2, an increase in the size of protests is 27 percent less likely to cause a change in democratic progress. As Graph 1 indicates, the probability of democratic progress decreases as campaigns grow larger. Even though protests incorporate a large portion of the population, the size hardly causes states to become more authoritarian or democratic. Larger protests do not cause a state to experience democratic progress.

According to Table 1, protests that are nonviolent are more likely to cause at least a two point change in democratic progress. States that experience primarily violent protests are less likely to experience democratic progress than campaigns that are primarily nonviolent. According to Table 2, primarily nonviolent protests are 74 percent more likely to cause democratic progress. Campaigns that begin as primarily nonviolent allow states to progress democratically.

The duration of campaigns is not statistically significant. According to this study, the length of movements does not have an impact on democratic progress, although more participants typically join as protests continue. The duration of campaigns does not bring about any significant change in regards to states' progress democratically for this study.

Although the goal of a campaign is not a variable of interest, the relationship in this study needs to be addressed. Campaign goals are coded inversely in NAVCO 2.0. The data is coded in a way that the more intense goals such as regime change are lower numbers while less extreme goals are higher numbers. As the protesters begin to take the offensive, campaigns are likely to result in democratic progress. The negative designation indicates that when goals move toward regime change, the movement is likely to bring about democratic progress instead of when the 
group has less offensive goals such as anti-occupation. Groups that have aspirations of regime change are more likely to produce democratic progress.

\section{Discussion}

The main question addressed by this study is whether protest characteristics move states toward democracy or toward authoritarianism. The results above begin the discussion about protest characteristics and their effect on democratic progress. Protest size is shown not to move states over the two point change in polity2 scores. Violence is shown to not produce democratic progress. Finally, campaign duration and location diversity are not statistically significant in this study.

The first hypothesis expected protests that were primarily violent would not lead to democratic progress. This hypothesis is confirmed because protests that were primarily nonviolent are more likely to produce democratic progress after five years. Protests that are violent did not produce a shift toward democracy. Violence causes the government to repress the movement, which is less likely to cause democratic progress. Protests that are nonviolent are more likely to invite government concessions that produce democratic progress.

Hypothesis number two expected that larger protests would not lead to democratic progress. This hypothesis is confirmed because larger protests are less likely to produce democratic progress. As the size of the protests increase, different groups come under the umbrella of the movement. Larger movements are likely to have different goals because the different factions lead to intergroup fighting or create another movement that runs counter to the original protests before it increased in size. Pro-democracy supporters now have a vested interest to form small protests because once they begin to increase in size the state is less likely to progress toward democracy. 


\section{Conclusion}

The main focus of this study is how characteristics of protests affect democratic progress. This question is an attempt to fill in the gap of the existing literature that has only unpacked protests to violent and nonviolent. Protests are a timely issue with the current unrest in Egypt that led to the ousting of democratically elected President Morsi. The major implications from this study are that it begins to unpack protests beyond violent and nonviolent. Its results indicate that certain characteristics move states toward democratic progress.

One of the main weaknesses of this study is that there are no exact numbers in regards to the size of the protests. The protests were divided into ordinal groups and coded based on these broad ranges. Campaign size is divided into five categories that cover from one participant to over one million participants. Also, some states had multiple protests within a given year. The multiple movements were combined into one which increased the number of ordinal categories for size. This study would have benefited from using the actual numbers of protest participants. The actual sizes would have provided a clearer picture of how large the protests were, unlike ordinal categories. Exact numbers would have provided this study with the ability to test how large protests are able to become before democratic progress decreases.

In addition, this study was not able to examine the number of deaths as a measure of violence. NAVCO 2.0 only provides whether a movement is primarily violent or nonviolent. It did not include the number of deaths during a given protest or the number of deaths over a given year. This would have been a better measure of violence than whether a movement was primarily violent or not.

By not including exact numbers, this study is limited in what it is able to measure. In the case of violence, exact numbers of deaths would have provided this study with the ability to 
examine how much violence occurred before democratic progress decreased. The use of exact numbers would have provided this study the ability to view the difference in small and large protests regarding whether either caused any change in democratic progress.

Another weakness of this study is that NAVCO 2.0 only takes into account whether there was location diversity within campaigns. This study would have benefited from the number of other major cities that the movements spread to over their duration. NAVCO only codes for diversity, but it does not account for the number of major cities that witnessed protests. This measure would have provided this study with the ability to test for how many cities a protests spreads to before it leads to or away from democratic progress. These are some of the weaknesses within this study.

Future research might continue to unpack protests. This study just scratched the surface with regard to protest characteristics. There are many more characteristics to be studied in terms of their effect on democratic progress. Protests are timely issues that should continue to be unpacked. If certain characteristics move states toward democracy, this information is important for pro-democracy protesters to try and shape movements around the features of protests that lead to democracy. The unpacking of protests provides numerous opportunities for future research since this topic is just beginning to be studied.

Another future research topic that is derived from this study is whether changes in protest goals lead to or away from democracy. The campaigns' goals are statistically significant as a control in this study. As protests grow and spread, it is important to see whether the original goal changes as more groups join the movement. The goals of protesters are vital to whether states become more democratic or more authoritarian. When these goals change or what causes the original goals to change are going to become vital questions as research on protests proceeds. 
The main implication of this study is that it identified some characteristics of protests that are significant in whether states experience democratic progress. This study indicates two variables of interest that are significant during protests and two control variables that are significant. Future research can expand on the findings of this study by continuing to unpack protests. 


\section{References}

Beissinger, Mark R. 2007. "Structure and Example in Modular Political Phenomena: The Diffusion of Bulldozer/Rose/Orange/Tulip Revolutions." Perspectives on Politics 5(2): 259-276.

Celestino, M. R., and K. S. Gleditsch. 2013. "Fresh Carnations or All Thorn, No Rose? Nonviolent Campaigns and Transitions in Autocracies." Journal of Peace Research 50(3): 385-400.

Chenoweth, Erica, and Orion A. Lewis. 2013. "Unpacking nonviolent campaigns: Introducing the NAVCO 2.0 dataset." Journal of Peace Research 50(3): 415-423.

Chenoweth, Erica, and Orion A Lewis. 2013. "Nonviolent and Violent Campaigns and Outcomes ( NAVCO ) Data Project Campaign-Year Data Codebook." (May): 1-19.

Conrad, Courtenay R., and Jacqueline H. R. DeMeritt. 2011. "Human Rights Advocacy and State Repression Substitutability.” Presented at the American Political Science Association, Seattle, WA.

Cunningham, K. G. 2013. "Understanding Strategic Choice: The Determinants of Civil War and Nonviolent Campaign in Self-Determination Disputes." Journal of Peace Research 50(3): 291-304.

Fearon, James D., and David D. Laitin. 2003. "Ethnicity, Insurgency, and Civil War." American Political Science Review 97(01): 75.

Gartner, Scott Sigmund, and Patrick M Regan. 1996. “Threat and Repression: The Non-Linear Relationship Between Government and Opposition Violence." Journal of Peace Research 33(3): 273-287.

Geddes, Barbara. 1999. "What Do We Know About Democratization After Twenty Years?" Annual Review of Political Science (2): 115-144.

Huntington, Samuel P. 1991. "How Countries Democratize.” Political Science Quarterly 106(4): 579-616.

Jalali, Rita, and Seymour Martin Lipset. 1992. "Racial and Ethnic Conflicts: A Global Perspective.” Political Science Quarterly (Winter): 585-606.

Joshi, Madhav. 2010. "Post-Civil War Democratization: Promotion of Democracy in Post-Civil War States, 1946-2005." Democratization 17(5): 826-855.

Kalandadze, Katya, and Mitchell A Orenstein. 2009. "Electoral Protests and Democratization." Comparative Political Studies 42(11): 1403-1425. 
Lichbach, Mark Irving, and Ted Robert Gurr. 1981. "The Conflict Process: A Formal Model." The Journal of Conflict Resolution 25(1): 3-29.

Lichbach, Mark Irving. 1987. "Deterrence or Escalation? The Puzzle of Aggregate Studies of Repression and Dissent." The Journal of Conflict Resolution 31(2): 266-297.

Mainwaring, Scott. 1989. "Transitions to Democracy and Democratic Consolidation." Helen Kellogg Institute for International Studies 130(November): 1-43.

Marshall, Monty G. and Ted Robert Gurr, 2013. "Polity IV Project: Political Regime Characteristics and Transitions, 1800-2012.”. http://www.systemicpeace.org/polity4.htm

Stephan, Maria J, and Erica Chenoweth. 2008. "Why Civil Resistance Works: The Strategic Logic of Nonviolent Conflict.” International Security 33(1): 7-44.

World Development Indicators. 2013. The World Bank, Washington, D.C.: World Bank Group. http://data.worldbank.org/data-catalog/world-development-indicators 
Table 1: Protest Characteristic Model on Democratic Progress

\begin{tabular}{lccc}
\hline Polity ${ }^{2}$ after 5 Years & Coefficient & $\begin{array}{c}\text { Standard } \\
\text { Error }\end{array}$ & $\begin{array}{c}\text { Statistical } \\
\text { Significance }\end{array}$ \\
\hline Campaign Size & $\mathbf{- . 2 3 4 7}$ &. $\mathbf{1 3 7 7}$ & $\mathbf{0 . 0 8 8 *}$ \\
Urban/Rural Diversity & .1759 & .2828 & 0.534 \\
Primary Method (V/NV) & $\mathbf{2 . 0 7 8 6}$ & $\mathbf{. 3 1 9 2}$ & $\mathbf{0 . 0 0 0 * * * *}$ \\
Campaign Years & -.1338 & .2595 & 0.606 \\
Campaign Goals & $\mathbf{- . 2 8 3 2}$ & $\mathbf{. 0 9 4 0}$ & $\mathbf{0 . 0 0 3 * * *}$ \\
Repression & .1657 & .1613 & 0.304 \\
Diaspora Support & .1000 & .3524 & 0.777 \\
Campaign Backlash &. $\mathbf{2 2 8 3}$ &. $\mathbf{1 3 8 1}$ & $\mathbf{0 . 0 9 8 *}$ \\
West & 1.750 & 1.5630 & 0.263 \\
Eastern Europe & .7994 & .9214 & 0.386 \\
Latin America & -.1379 & .7713 & 0.858 \\
Sub-Saharan Africa & .2323 & .7362 & 0.752 \\
Asia & -.5749 & .7679 & 0.454 \\
Ethnic Fractionalization & -.5789 & .9487 & 0.542 \\
GDP per capita & -.0001 & .0001 & 0.185 \\
Constant & -1.1856 & .8435 & 0.160 \\
\hline n = 737 Wald Chi ${ }^{2}=93.25$ & $\mathrm{p} \leq .10^{*} \leq .05 * * .01 * * * \leq .001 * * * *($ Two-tailed)
\end{tabular}


Table 2: Probability of Democratic Progress

\begin{tabular}{lcc}
\hline & Mean & $\begin{array}{c}\text { Standard } \\
\text { Error }\end{array}$ \\
\hline Campaign Size & -.2662 & .1053 \\
Nonviolence & .7422 & .0528 \\
Location Diversity & -.1203 & .1747 \\
Duration & -.0519 & .1518
\end{tabular}




\section{Graph 1}

The Effects of Campaign Size on Democratic Progress

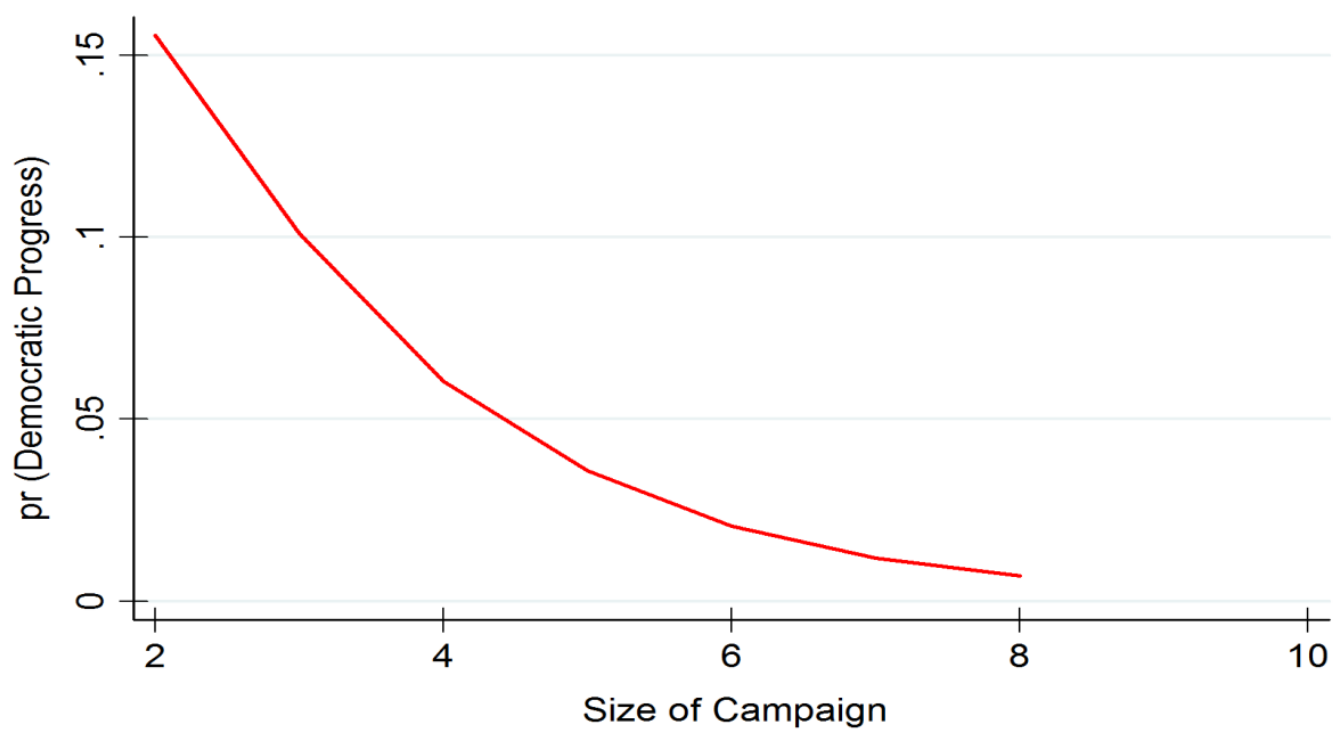


Figure 2: Effects of Violence on Democratic Progress

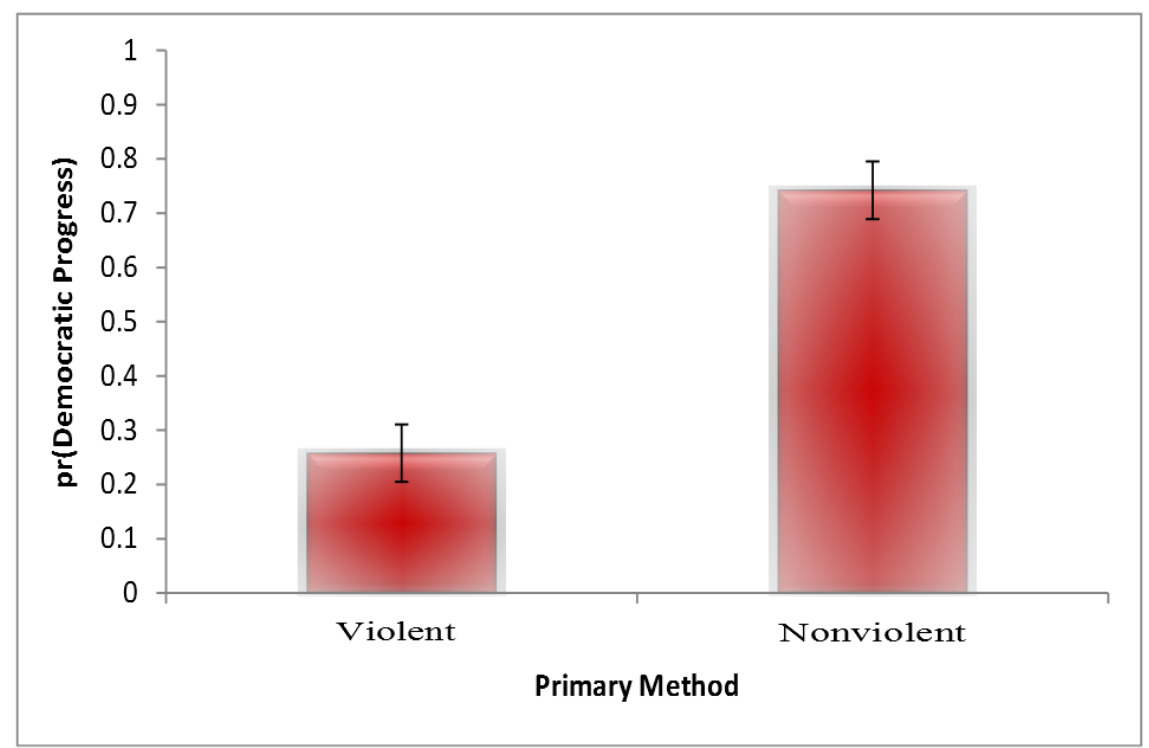

